\title{
Importation of Ticks on Companion Animals and the Risk of Spread of Tick-Borne Diseases to Non-Endemic Regions in Europe
}

\author{
Alicja Buczek* *iD and Weronika Buczek
}

check for updates

Citation: Buczek, A.; Buczek, W. Importation of Ticks on Companion Animals and the Risk of Spread of Tick-Borne Diseases to Non-Endemic Regions in Europe. Animals 2021, 11, 6. https://dx.doi.org/10.3390/ani11 010006

Received: 17 November 2020 Accepted: 16 December 2020 Published: 22 December 2020

Publisher's Note: MDPI stays neutral with regard to jurisdictional claims in published maps and institutional affiliations.

Copyright: () 2020 by the authors. Licensee MDPI, Basel, Switzerland. This article is an open access article distributed under the terms and conditions of the Creative Commons Attribution (CC BY) license (https: / / creativecommons.org/ licenses/by/4.0/).
Chair and Department of Biology and Parasitology, Faculty of Health Sciences, Medical University of Lublin, 20-080 Lublin, Poland; wera1301@gmail.com

* Correspondence: alicja.buczek@umlub.pl; Tel.: +48-814-486-060

Simple Summary: The risk of transmission of pathogen-infected ticks by dogs and cats transported by humans has increased substantially in recent decades due to the rise in tourist and economic migration rates. Therefore, we highlight the role of companion animals, mainly dogs, travelling with their owners or importation of these animals in the transmission of ticks and tick-borne diseases to non-endemic areas. The brown dog tick Rhipicephalus sanguineus, which is a vector of numerous pathogens causing diseases in animals and humans, is imported most frequently to many European countries from endemic areas in the Mediterranean region or from other parts of the world. Additionally, alien tick species with high epizootic and epidemiological importance can be imported while attached to dog skin to Europe from other continents. Companion animals play an even greater role in the spread of autochthonous tick species and transmission of pathogens to other animals and humans. Before travelling to endemic areas of tick-borne diseases, tourists should be acquainted with prophylaxis methods to protect themselves and their companion animals against tick attacks.

Abstract: Increased human mobility elevates the risk of exposure of companion animals travelling with their owners or imported from other regions to tick attacks. In this study, we highlight the potential role of dogs and cats taken for tourist trips or imported animals in the spread of ticks and tickborne pathogens. The Rhipicephalus sanguineus tick, which is a vector of numerous pathogens causing diseases in animals and humans, is imported most frequently from endemic areas to many European countries. Additionally, alien tick species with high epizootic and epidemiological importance can be imported on dogs from other continents. Companion animals play an even greater role in the spread of autochthonous tick species and transmission of tick pathogens to other animals and humans. Although the veterinary and medical effects of the parasitism of ticks carried by companion animals travelling with owners or imported animals are poorly assessed, these animals seem to play a role in the rapid spread of tick-borne diseases. Development of strategies for protection of the health of companion animals in different geographic regions should take into account the potential emergence of unknown animal tick-borne diseases that can be transmitted by imported ticks.

Keywords: ticks; companion animals; importation of ticks; ticks on travelling dogs; transmission of tick-borne pathogens

\section{Introduction}

Companion animals, such as dogs (Canis lupus familiaris) and cats (Felis catus), can be hosts for various tick species from the family Ixodidae [1-9]. In Europe, these animals are parasitized by tick species from the genera Dermacentor, Haemaphysalis, Hyalomma, Rhipicephalus, and Ixodes [10,11]. In the northern, western, and central parts of the continent, companion animals are most often attacked by the sheep tick Ixodes ricinus, the hedgehog tick $I x$. hexagonus, the dog tick Ix. canisuga, and the meadow tick Dermacentor reticulatus. The most frequent attacks in the north-eastern part of Europe are ascribed to the taiga tick 
Ix. persulcatus, whereas the brown dog tick Rhipicephalus sanguineus and Rh. turanicus have been reported to infest animals primarily in the southern part of Europe. Other tick species (e.g., the red sheep tick Haemaphysalis punctata, the rodent tick $\mathrm{Ha}$. concinna, the ornate sheep tick De. marginatus, and the southern rodent tick Ix. acuminatus) infest dogs and cats less frequently [12-19]. The Mediterranean ticks Hyalomma marginatum marginatum and Hy. Iusitanicum [16,20,21] and the rodent tick Ix. trianguliceps [16,22] have been found to attack dogs sporadically. In the group of ticks that parasitize dogs and cats, there are two species (i.e., Rh. sanguineus and Ix. canisuga) associated with the human environment, in which their entire development cycle can be completed. A majority of ticks parasitizing companion animals can attack humans (e.g., [23-25]).

Companion animals travelling with their owners over long distances on the same continent or between continents are exposed to an increased risk of infestations by various species of ticks with considerable vector competence and infection with pathogens transmitted by these ticks. Most often, ticks are imported on dogs or cats in the parasitic stage. However, unattached ticks can also be found in animal fur or transport containers, and later reach the skin of other animals or their keepers

The spread of ixodid ticks by companion animals and infection of these hosts with tickborne pathogens during tick feeding is facilitated by specific biological and physiological features distinguishing these arthropods from other bloodsucking ectoparasites.

Ticks are attached to host skin for several days or even weeks. depending on the species and developmental stage [26-28], and their feeding dynamics may be influenced by various factors, including the intensity of invasion [29], the presence of ticks from the same or different species co-feeding on the same host [30], the sexual structure of foraging specimens [31], and climate conditions [32].

During blood ingestion, infected ticks can introduce factors of tick-borne diseases contained in tick saliva (e.g., viruses, bacteria, and protozoa) into the host. Canine babesiosis (Babesia spp.), borreliosis (Borrelia burgdorferi s.l.), ehrlichiosis (Ehrlichia spp.), rickettsiosis (Rickettsia spp.), and anaplasmosis (Anaplasma spp.) [19,33-39] are the most common tick-borne diseases in dogs and/or cats.

Skin lesions (granuloma, alopecia) and allergic reactions [16,40-47] as well as tick paralysis caused by the neurotoxic components of tick saliva [48-53] are the direct effects of tick parasitism in companion animals. In dogs, tick bites may induce production of specific immunoglobulin E antibodies to oligosaccharide galactose- $\alpha-1$, 3-galactose (anti- $\alpha$-Gal antibodies), which can be a source of red meat allergy [54].

Incidents of importation of ticks to new areas by animals transported by humans have been repeatedly described in the world literature [55-60]. A majority of reports have described importation of ticks by exotic reptiles transported from endemic areas to other regions of the world [55,61-67]. However, the scale of this phenomenon and the potential threat to animal and human health posed by imported ticks and pathogens in the new environment have rarely been assessed.

In this study, we highlight the role of companion animals, mainly dogs, travelling with their owners or importation of these animals in the transmission of ticks and tick-borne diseases to non-endemic areas. We also emphasize the role of dogs and cats in the spread of autochthonous tick and pathogen species.

The risk of transmission of pathogen-infected ticks by dogs and cats transported by humans has increased substantially in recent decades due to the rise in tourist and economic migration rates. Most agents of tick-borne diseases (e.g., Borrelia spirochetes [13,68-71], Rickettsia [69,70,72-74], Anaplasma phagocytophilum [68,71,73], and tick-borne encephalitis virus (TBEV) [75,76]) are pathogenic to not only companion animals but also humans $[25,73,77]$. Companion animals and humans can also be infected with bacteria, protozoa, and helminths transmitted by other vectors (e.g., fleas, mosquitoes, and phlebotomine sand flies; [78-80]). Therefore, clinical and laboratory methods for diagnostics of diseases transmitted by ticks and other bloodsucking arthropods, which facilitate 
identification of the pathogenic factor and effective treatment, arouse increasing interest (e.g., [25,81-87]).

Due to the increase in the incidence of animal and human tick-borne diseases recorded worldwide, there is a need to trace the potential routes of transmission thereof to areas where they did not occur or rarely appeared previously. Determination of these routes will prompt effective measures for limiting the harmful results of tick parasitism.

\section{Alien and Autochthonous Ticks and Tick-Borne Pathogens Carried by Travelling and Imported Companion Animals}

Cases of transport of ticks and associated pathogens by companion animals have been reported in various countries, but only some countries have monitored this process. In Europe, the role of dogs in the transmission of autochthonous and exotic tick species has been assessed, specifically in Germany [88-95], the UK [17,20,96,97], Benelux countries [98,99], Sweden [100], Switzerland [101], Hungary [15,102], Cyprus [103], Greece [104], Italy [105], Spain [106], and Portugal [107]. However, there are very few reports on the role of transported cats in the transmission of ticks to other habitats [108-110], which is probably related to the fact that cats accompany their travelling owners less frequently than dogs. Additionally, cats usually stay indoors when they accompany their owners and are thus not exposed to contact with ticks present in the environment.

Tick infestations and transmission of pathogens in dogs and cats are supported by the presence of tick species with high epidemiological importance in urban and suburban areas that are often visited by owners of these animals. An example is the occurrence of $R h$. sanguineus, Rh. turanicus, Rh. bursa, Ix. ricinus, De. marginatus, and Ha. punctata in the parks of Rome and other Italian cities [111-113] and the Rh. sanguineus group, Ha. parva, Hy. marginatum, Rh. bursa, Ix. ricinus, De. marginatus, Hy. anatolicum, Hy. detritum, Hy. excavatum, and Ha. punctata in Ankara (Turkey) [114]. The likelihood of infection of companion animals with pathogens in these areas is associated with the level of the prevalence of these microorganisms in ticks, which is higher than in natural habitats [115-118].

Dogs are usually infested by tick adult stages [15,16], less often by nymphs [15,16,106], and sporadically by larvae $[16,20,22,46,119]$. Dog's head (especially the eye area, ears, and muzzle), legs, and neck are the most commonly attacked body areas [16,120,121]. The frequency of tick attachment to the skin is associated with the breed of dogs and their temperament [120]. In cats, the greatest number of ticks attach to the head (ears, chin, face, and muzzle) and the neck [121].

In the world, Rh. sanguineus sensu lato is the most commonly imported dog tick (e.g., $[20,101,109,122-124])$. This species is distributed in large areas in warm climate regions in both hemispheres, where it can be found in kennels, buildings, and gardens [4,125].

$R h$. sanguineus is a common tick species in the Mediterranean region, from where specimens are most often imported on dogs to countries in the central and northern part of the continent, including the UK [109,126-129], Germany [88,92,130-135], Poland [136], the Czech Republic [137,138], the Netherlands [98,139], Denmark [140-143], Belgium [108, 144], and Switzerland [145]. Less frequently, Rh. sanguineus ticks are transferred to European countries from other endemic areas of this species, like the Dominican Republic [88] and Sudan [140]. As shown in literature, the number of these cases clearly increased after the economic and political transformations in Europe at the end of the 20th century. This is associated with the growing interest in tourism and business trips to remote locations in Europe, Americas, Africa, and Asia, where high prevalence of ticks from the Rh. sanguineus group in dogs from urban and rural environments is observed. For instance, Rh. sanguineus sensu lato (s.1.) has been found to attack 63.6\% of autochthonous dogs in Italy [146], 53\% in Spain [106], 51.32\% in Northern Algeria [147], 59.6\% on the Mexico-USA border [148], $80 \%$ in north-central Nigeria [149], 80\% in north-eastern Thailand [150], and as many as 98.33\% in Punjab, Pakistan [151]. Similarly, in the endemic areas of the Rh. sanguineus group (Rh. sanguineus sensu stricto, and Rh. pusillus) in southern Italy, these species most often infest cats [152]. 
Travelling and imported dogs have been shown to be infested by the largest number of adults and nymphs but only single larvae of Rh. sanguineus and other tick species [20]. An unusual case was the transfer of approximately 50 or more mobile engorged and unfed $R h$. sanguineus larvae infesting a five-old Jack Russel, which was noticed $18 \mathrm{~h}$ after the dog had returned from Greece [153].

The importation of $R h$. sangiuneus s.l. ticks on animals to non-endemic areas has considerable importance for public health, as they are vectors and/or potential reservoirs of numerous pathogens. These include Ehrlichia canis, Anaplasma platys, and A. phagocytophilum, protozoa Babesia vogeli, B. canis, Babesia vulpes, and Hepatozoon canis, zoonotic Rickettsia species (Rickettsia conorii complex and R. massiliae), and the filarioid nematode Cercopithifilaria bainae [154-160]. Besides Rh. sanguineus, other alien tick species were occasionally transported by dogs to various European countries (Tables 1 and 2).

Table 1. Examples of alien ticks imported on dogs and cats into non-endemic areas in Europe.

\begin{tabular}{|c|c|c|c|}
\hline Tick Species & $\begin{array}{c}\text { Areas of Tick Infestations of } \\
\text { Dogs or Cats }\end{array}$ & Place of Import of Ticks & $\begin{array}{c}\text { Source of Information } \\
\text { Authors, [Ref.] }\end{array}$ \\
\hline Ixodes holocyclus & Australia & United Kingdom (UK) & Adamantos et al. [49] \\
\hline Ixodes pacificus & USA & UK & Jameson et al. [109] \\
\hline Amblyomma americanum & USA & UK & Jameson et al. [109] \\
\hline Dermacentor variabilis & USA & UK & $\begin{array}{c}\text { Abdullah et al. [17]; Jameson } \\
\text { et al. [109] }\end{array}$ \\
\hline Dermacentor albipictus & USA & UK & Jameson et al. [109] \\
\hline \multirow[t]{2}{*}{ Haemaphysalis leachi } & $\begin{array}{c}\text { South Africa, Tanzania, } \\
\text { Zambia }\end{array}$ & UK & Dutto and Selmi [16] \\
\hline & $\begin{array}{c}\text { Rhodesia (Zimbabwe), South } \\
\text { Africa, Tanzania, Zambia }\end{array}$ & UK & Jameson et al. [109] \\
\hline Haemaphysalis elliptica & South Africa & UK & Hansford et al. [123] \\
\hline Hyalomma lusitanicum & Portugal & UK & Hansford et al. [20] \\
\hline \multirow[t]{10}{*}{ Rhipicephalus sanguineus } & Sudan & Denmark & Winding and Haarløv [140] \\
\hline & Zambia & Denmark & Haarløv [141] \\
\hline & No data & Denmark & Winding et al. [142] \\
\hline & No data & Denmark & Willeberg [143] \\
\hline & $\begin{array}{l}\text { Spain, Dominican Republic, } \\
\text { Italy, France, Greece }\end{array}$ & Germany & Dongus et al. [88] \\
\hline & No data & Belgium & Claereboutt et al. [108] \\
\hline & No data & UK & Hansford et al. [123] \\
\hline & Cyprus, Spain & UK & Hansford et al. [123] \\
\hline & $\begin{array}{c}\text { Africa, Australia, Canada, } \\
\text { Iran, Malta, Philipines, } \\
\text { Singapore, West Indies, Saudi } \\
\text { Arabia, South Africa, } \\
\text { Mideterranean region (Spain, } \\
\text { Cyprus, Tunisia), USA }\end{array}$ & UK & Jameson et al. [109] \\
\hline & Greece & UK (London) & Wright et al. [121] \\
\hline Haemaphysalis leachi ${ }^{*}$ & Africa & UK & Jameson et al. [109] \\
\hline
\end{tabular}


Table 2. Examples of autochthonous tick species carried by imported and travelling dogs in Europe

\begin{tabular}{cccc}
\hline Tick Species & $\begin{array}{c}\text { Areas of Tick } \\
\text { Infestations of Dogs }\end{array}$ & $\begin{array}{c}\text { Place of Import of } \\
\text { Ticks }\end{array}$ & $\begin{array}{c}\text { Source of } \\
\text { information } \\
\text { Authors, [Ref.] }\end{array}$ \\
\hline Ixodes ricinus & $\begin{array}{c}\text { Belgium, The } \\
\text { Netherlands, } \\
\text { Germany } \\
\text { Finland }\end{array}$ & $\begin{array}{c}\text { United Kingdom } \\
\text { (UK) } \\
\text { UK }\end{array}$ & $\begin{array}{c}\text { Jameson et al. [109] } \\
\text { Hansford et al. [123] }\end{array}$ \\
\hline Ixodes hexagonus & Germany & UK & Jameson et al. [109] \\
\hline Ixodes ventalloi & France & UK & Hansford et al. [123] \\
\hline Dermacentor & France & UK & Hansford et al. [123] \\
reticulatus & France, Bulgaria & Northwest Italy & Dutton and Selmi [16] \\
\hline
\end{tabular}

Some of these tick species can live in new habitats with favourable conditions. Engorged females lay eggs, and juvenile stages (larvae and nymphs) transform into subsequent developmental stages. Hungry active stages of these ticks can attack hosts present in the surroundings $[88,161]$. The introduction of some species (Rh. sanguineus, Hy. marginatum, Hy. suspense) to non-endemic areas is possible due to the climate and environmental changes occurring worldwide (e.g., $[145,162,163])$.

An interesting case of introduction of $R h$. sanguineus to Poland and mass reproduction of this tick in an apartment in Warsaw was described by Szymański [136]. These ticks from a dog travelling with an Italian family infested the dog of the Polish family when they spent holidays together in the Mazury region. After return to Warsaw, an engorged $R h$. sanguineus female detached from the host skin and laid eggs, from which larvae developed. Rh. sanguineus ticks can complete their full life cycle indoors. Cases of household $R h$. sanguineus infestations have been reported from other countries as well, including Germany [88], England [96,97,164], and France [165].

In Europe, dogs and cats most frequently transfer autochthonous species of ticks, which are vectors of numerous animal tick-borne diseases. For instance, a group of 2373 ticks removed from dogs and cats in Belgium was dominated by the castor bean tick Ix. ricinus $(76.4 \%)$ and the European hedgehog tick Ix. hexagonus $(22.6 \%)$; single specimens of the meadow tick De. reticulatus $(0.8 \%)$ were found as well. $R h$. sanguineus specimens, which accounted for $0.3 \%$ of the total number, were found on dogs after return from endemic areas of this tick species [108].

In the UK in 2005-2016, Rh. sanguineus (46.2\%) and I. ricinus (33.8\%) ticks were the most common species of ticks found on animals with a history of travel mainly to southern Europe, the USA, and the United Arab Emirates [20]. In Spain, Rh. sanguineus s.l. (53\%) was the most abundant autochthonous species in a group of 1628 collected adult ticks. Other ticks accounted for a lower percentage: De. reticulatus $(9 \%)$, Ix. ricinus $(9 \%)$, and $I x$. hexagonus $(4 \%)$. In a group of 660 dogs sampled in 26 veterinary clinics, as many as 507 dogs $(76.8 \%)$ were infested by at least one adult tick [86]. In Greece, the majority of ticks infesting 150 dogs (48.4\%) were $R h$. sanguineus s.l. (70.1\%), whereas other species were less numerous (i.e., Ha. parva (14.7\%), Rh. turanicus (11.4\%), and Ha. concinna (2.4\%)). A total of $11.1 \%$ of 344 sampled ticks were vectors of at least one microorganism (5.5\%: Cercopithifilaria bainae, 2.9\%: Hepatozoon canis, 1.7\%: Rickettsia hoogstraalii, 1.2\%: Hepatozoon felis, $0.6 \%$ : Rickettsia massiliae, $0.6 \%$ : Theileria ovis, $0.3 \%$ : Anaplasma platys, and $0.3 \%$ : Coxiella like-endosymbiont) [166].

$R h$. sanguineus transferred on travelling and imported dogs into non-endemic areas may pose a health risk by transmission of pathogens (e.g., Ehrlichia canis) to native dogs $[167,168]$. Canine hepatozoonosis caused by the apicomplexan protozoan Hepatozon canis was diagnosed in three dogs imported to the United Kingdom from Mediterranean 
countries [169]. The infection by pathogens acquired by animals in the travel destination area is often confirmed by serological tests only after returning home [170]. Dogs are a reservoir of infectious agents of human diseases, like Mediterranean spotted fever caused by Rickettsia conorii [171,172].

Various microorganisms were detected in $R h$. sanguineus ticks carried into new areas on dogs, including Ri. conorii [173,174], Ri. massiliae/Bar29, and Coxiella sp. [175]. Contact with dogs or cats infested by pathogen-infected $R h$. sanguineus ticks increases the likelihood of the spread of tick-borne pathogens, like spotted fever group (SFG) rickettsiae. Symptoms of spotted fever group (SFG) rickettsiosis were confirmed in members of a family from south France living in a house where $22 \mathrm{Rh}$. sanguineus ticks were collected from the floor behind furniture. Of these ticks, 20 were infected with Rickettsia; more specifically, nine and seven specimens were infected by Ri. conorii subsp. caspia and Ri. massiliae, respectively, whereas both rickettsiae were identified in four ticks [165]. As shown by Edouard et al. [176], some patients in France were diagnosed with rickettsiosis caused by Ri. sibrica mongolitimonae, another representative of the spotted fever group. Ri. massiliae and Ri. sibirica mongolitimonae were detected in $R h$. sanguineus and Rh. pusillus ticks sampled from their dogs and cats, respectively. $R h$. pusillus ticks infected by Ri. sibirica mongolitimonae were also collected from cats' litter boxes and beds. There are reports of cases of human infection with Ri. conorii contracted during removal of ticks from dogs [177].

An especially high risk of development of tick-borne and other arthropod-borne diseases in companion animals has been observed in attractive tourist regions characterized by a high prevalence of pathogens transmitted by ticks and other arthropods (e.g., [79,178-185]). For instance, it was reported that the prevalence of Ri. conorii in dogs in southern Italy ranged from $72 \%$ to $73.60 \%$. The prevalence of An. phagocytophilum was in the range from $32.80 \%$ to $38 \%$, B. canis from $5.17 \%$ do $70 \%$, and Eh. canis from $21.70 \%$ to $46 \%$. The prevalence of Co. burnetii was estimated at $31.50 \%[181,186]$.

In the north of Spain, antibodies against these pathogens were detected in $11.33 \%$ of tested dogs, with prevalence of $1.26 \%$ for Anaplasma spp., $0.9 \%$ for Eh. canis, and $0.72 \%$ for Bo. burgdorferi transmitted by ticks and $8.99 \%$ for Le. infantum and $0.18 \%$ for Di. immitis transmitted by sand flies and culicid mosquitoes, respectively [187].

\section{Tick Preventive Behaviors and Practices of Dog and Cat Owners}

The effects of tick parasitism on companion animals and their owners can be limited by application of various methods for protection against tick attacks recommended by the Centers for Disease Control and Prevention [188] and the European Scientific Counsel Companion Animal Parasites [189].

The risk of human and animal contact with ticks can be minimized by avoidance of habitats with high numbers of ticks at the peak of their seasonal and diurnal activity. Another important element of tick prophylaxis is the preventive behavior of animal owners outdoors (e.g., limitation of contact with plants, avoidance of sitting on grass and under shrubs, wearing protective clothes to prevent ticks from attachment to the skin, inspection of clothes or skin to find ticks), and removal of the feeding tick from the skin as soon as possible after attachment. Tick attacks can be limited with effective repellents (e.g., [190]). As shown in various studies, inspection of the body on return home, wearing protective clothes, and the use of repelents are the most preferred methods used by humans for personal protection against tick attachment to the skin [191-197].

Owners of dogs and cats are advised to inspect the hair and skin of their animals, especially the head, ears, shoulders, and upper leg areas, when the animals stay outdoors during the tick activity period. They should also use various acaricidal and/or repellent substances contained in numerous formulations available on the market (e.g., spot-on, pour-on, baths, and insecticide-impregnated collars).

Orally administered parasiticides against ticks are also effective in protecting dogs against ticks and tick-borne pathogens (e.g., [198-202]). A single oral dose reduced the 
survival rate of over $98 \%$ of ticks present on the host $48 \mathrm{~h}$ after treatment and effectively protected against new infestations for several weeks [198,199].

Specimens attached to host's skin are removed with various methods described in various publications (e.g., [203,204]).

\section{Conclusions}

The most important role in rapid transmission of ticks and associated pathogens over long distances is ascribed to seasonally migrating birds (e.g., [205-210]). Nevertheless, it seems that animals accompanying their owners during foreign and domestic journeys or animals imported from other geographic regions may contribute considerably as well. The problem has to be emphasised to draw attention of owners of dogs and cats as well as veterinary staff, due to the dramatic increase in the prevalence of tick-borne diseases in these animals (e.g., [19,79,211-217]).

Before travelling to endemic areas of tick-borne diseases, tourists should be acquainted with prophylaxis methods to protect themselves and their companion animals against tick attacks. Information about tick species that infest dogs and cats most frequently, periods of the highest tick questing activity, and threats of zoonotic tick-borne diseases posed to animal health is indispensable for owners of companion animals.

Author Contributions: Conceptualization, A.B.; writing and reviewing of the original draft and supervision, A.B.; writing of the original draft and editing, W.B. All authors have read and agreed to the published version of the manuscript.

Funding: This research received no external funding.

Acknowledgments: In this section you can acknowledge any support given which is not covered by the author contribution or funding sections. This may include administrative and technical support, or donations in kind (e.g., materials used for experiments).

Conflicts of Interest: The authors declare no conflict of interest.

\section{References}

1. Hoogstraal, H. A preliminary, annotated list of ticks (Ixodoidea) of the Anglo-Egyptian Sudan. J. Parasitol. 1954, 40, 304-310. [CrossRef]

2. Arthur, D.R. Ticks and Disease; Pergamon Press: Oxford, UK, 1962; p. 445.

3. Nijhof, A.M.; Bodaan, C.; Postigo, M.; Nieuwenhuijs, H.; Opsteegh, M.; Fransses, L.; Jebbink, F.; Jongejan, F. Ticks and associated pathogens collected from domestic animals in the Netherlands. Vector Borne Zoonotic Dis. 2007, 7, 585-595. [CrossRef] [PubMed]

4. Kolonin, G.V. Fauna of Ixodid Ticks of the World (Acari, Ixodidae), Moscow. 2009. Available online: https:/ / www.kolonin.org/3. html (accessed on 24 August 2009).

5. Tsai, Y.-L.; Shyu, C.-L.; Yao, C.-T.; Lin, J.A. The ixodid ticks collected from dogs and other animals in Taiwan and Kinmen Island. Int. J. Acarol. 2012, 38, 110-115. [CrossRef]

6. Barker, S.C.; Walker, A.R. Ticks of Australia. The species that infest domestic animals and humans. Zootaxa 2014, 3816, 1-144. [CrossRef]

7. Portugaliza, H.P.; Bagot, M.A. Different species of lice (Phthiraptera), fleas (Siphonaptera) and ticks (Ixodida) collected from livestock, poultry, reptile and companion animal in Leyte Island, Philippines. LRRD 2015, 27, 1-10.

8. Durden, L.A.; Beckmen, K.B.; Gerlach, R.F. New records of ticks (Acari: Ixodidae) from dogs, cats, humans, and some wild vertebrates in Alaska: Invasion potential. J. Med. Entomol. 2016, 53, 1391-1395. [CrossRef]

9. Greay, T.L.; Oskam, C.L.; Gofton, A.W.; Rees, R.L.; Ryan, U.M.; Irwin, P.J. A survey of ticks (Acari: Ixodidae) of companion animals in Australia. Parasites Vectors 2016, 9, 207. [CrossRef]

10. Estrada-Peña, A.; Bouattour, A.; Camicas, J.L.; Walker, A.R. Ticks of Domestic Animals in the Mediterranean Region. A Guide of Identification of Species; University of Zaragoza Press: Zaragoza, Spain, 2004; p. 131.

11. Nowak-Chmura, M. Fauna Kleszczy (Ixodida) Europy Środkowej; Wyd. Naukowe Uniwersytetu Pedagogicznego: Kraków, Poland, 2013; p. 290.

12. Encinas Grandes, A. Ticks of the province of Salamanca (Central/NW Spain). Prevalence and parasitization intensity in dogs and domestic ungulates. Ann. Parasitol. Hum. Comp. 1986, 61, 95-107. [CrossRef]

13. Beichel, E. Tick infestation patterns and prevalence of Borrelia burgdorferi in ticks collected at a veterinary clinic in Germany. Vet. Parasitol. 1996, 65, 147-155. [CrossRef]

14. Ogden, N.H.; Cripps, P.; Davison, C.C.; Owen, G.; Parry, J.M.; Timms, B.J.; Forbes, A.B. The ixodid tick species attaching to domestic dogs and cats in Great Britain and Ireland. Med. Vet. Entomol. 2000, 14, 332-338. [CrossRef] 
15. Földvari, G.; Farkas, R. Ixodid tick species attaching to dogs in Hungary. Vet. Parasitol. 2005, 129, 125-131. [CrossRef] [PubMed]

16. Dutto, M.; Selmi, M. Report on ticks (Acari: Ixodidae) collected on dogs in Piedmont: The potential transmission of tick-borne pathogens to man. Parassitologia 2009, 51, 113-117.

17. Abdullah, S.; Helps, C.; Tasker, S.; Newbury, N.; Wall, R. Ticks infesting domestic dogs in the UK: A large-scale surveillance programme. Parasites Vectors 2016, 9, 391. [CrossRef] [PubMed]

18. Medlock, J.M.; Hansford, K.; Vaux, A.G.C.; Cull, B.; Pietzsch, M.E.; Gillingham, E.L.; Johnson, N.; Phipps, L.P. Has the red sheep tick, Haemaphysalis punctata, recently expanded its range in England?: Haemaphysalis punctata in the U.K. Med. Vet. Entomol. 2018, 32. [CrossRef]

19. Rudek, M.; Buczek, W.; Buczek, A.M.; Błaszkiewicz, P.S.; Kulina, D.; Ciura, D.; Buczek, A. The state of research on the infestation of companion animals by ticks (Ixodida) and their epizootiological role in Poland. In Parasitic and Allergic Arthropods; Part 1; Buczek, A., Błaszak, C., Eds.; Koliber: Lublin, Poland, 2019; pp. 73-89.

20. Hansford, K.M.; Medlock, J.M.; Atkinson, B.; Santos-Silva, M.M. Importation of a Hyalomma lusitanicum tick into the UK on a dog. Vet. Rec. 2016, 179, 415. [CrossRef]

21. Hansford, K.M.; Pietzsch, M.E.; Cull, B.; Gillingham, E.L.; Medlock, J.M. Potential risk posed by the importation of ticks into the UK on animals: Records from the Tick Surveillance Scheme. Vet. Rec. 2018, 182, 107. [CrossRef]

22. Manilla, G. Acari, Ixodida (Fauna d'Italia); Edizioni Cal-Derini: Bologna, Italy, 1998.

23. Bartosik, K.; Sitarz, M.; Szymańska, J.; Buczek, A. Tick bites on humans in the agricultural and recreational areas in south-eastern Poland. Ann. Agric. Environ. Med. 2011, 18, 151-157.

24. Földvári, G.; Rigó, K.; Lakos, A. Transmission of Rickettsia slovaca and Rickettsia raoultii by male Dermacentor marginatus and Dermacentor reticulatus ticks to humans. Diagn. Microbiol. Infect. Dis. 2013, 76, 387-389. [CrossRef]

25. Blanda, V.; Torina, A.; La Russa, F.; D’Agostino, R.; Randazzo, K.; Scimeca, S.; Giudice, E.; Caracappa, S.; Cascio, A.; de la Fuente, J. A retrospective study of the characterization of Rickettsia species in ticks collected from humans. Ticks Tick Borne Dis. 2017, 8, 610-614. [CrossRef]

26. Balashov, Y.S. Blood sucking ticks (Ixodidae)-vectors of diseases of man and animals. Misc. Publ. Entomol. Soc. Am. 1972, 8, 161-376.

27. Sonenshine, D.E.; Roe, M. Biology of Ticks; Oxford University Press: New York, NY, USA, 2014; Volume 1, p. 560.

28. Levin, M.L.; Schumacher, L.B.M. Manual for maintenance of multi-host ixodid ticks in the laboratory. Exp. Appl. Acarol. 2016, 70, 343-367. [CrossRef] [PubMed]

29. Bartosik, K.; Buczek, A. The impact of intensity of invasion of Ixodes ricinus and Dermacentor reticulatus on the course of the parasitic phase. Ann. Agric. Environ. Med. 2012, 19, 651-655. [PubMed]

30. Buczek, A.; Bartosik, K.; Zając, Z.; Stanko, M. Host-feeding behaviour of Dermacentor reticulatus and Dermacentor marginatus in mono-specific and inter-specific infestations. Parasites Vectors 2015, 8, 470. [CrossRef] [PubMed]

31. Bartosik, K.; Buczek, A.; Buczek, W.; Buczek, A.M.; Kulina, D.; Koman-Iżko, A. Host feeding behaviour of Dermacentor reticulatus males in relation to the transmission of pathogens. Ann. Agric. Environ. Med. 2019, 26, 227-230. [CrossRef]

32. Karbowiak, G.; Izdebska, J.N.; Czaplińska, U.; Wita, I. Cases of survival of the winter by Ixodidae ticks on the hosts in the Białowieża primeval forest. In Arthropods and Hosts; Buczek, A., Błaszak, C., Eds.; Koliber: Lublin, Poland, 2003 ; pp. 77-82.

33. Zygner, W.; Wiśniewski, M. Tick-transmitted diseases which may threaten health of dogs in Poland. Wiad. Parazytol. 2006, 52, 85-92. (In Polish)

34. Otranto, D.; Capelli, G.; Genchi, C. Changing distribution patterns of canine vector borne diseases in Italy: Leishmaniosis vs. dirofilariosis. Parasites Vectors 2009, 2 (Suppl. 1), S2. [CrossRef]

35. Pérez Vera, C.; Kapiainen, S.; Junnikkala, S.; Aaltonen, K.; Spillmann, T.; Vapalahtiet, O. Survey of selected tick-borne diseases in dogs in Finland. Parasites Vectors 2014, 7, 285. [CrossRef]

36. Pantchev, N.; Pluta, S.; Huisinga, E.; Nather, S.; Scheufelen, M.; Vrhovec, M.G.; Schweinitz, A.; Hampel, H.; Straubinger, R.K. Tick-Borne diseases (Borreliosis, Anaplasmosis, Babesiosis) in German and Austrian dogs: Status quo and review of distribution, transmission, clinical findings, diagnostics and prophylaxis. Parasitol. Res. 2015, 114, 19-54. [CrossRef]

37. Swainsbury, C.; Bengtson, G.; Hill, P. Babesiosis in dogs. Vet. Rec. 2016, 178, 172. [CrossRef]

38. Livanova, N.N.; Fomenko, N.V.; Akimov, I.A.; Ivanov, M.J.; Tikunova, N.V.; Armstrong, R.; Konyaev, S.V. Dog survey in Russian veterinary hospitals: Tick identification and molecular detection of tick-borne pathogens. Parasites Vectors 2018, 1, 591. [CrossRef]

39. Skotarczak, B. The role of companion animals in the environmental circulation of tick-borne bacterial pathogens. Ann. Agric. Environ. Med. 2018, 25, 473-480. [CrossRef] [PubMed]

40. Theis, J.H.; Budwiser, P.D. Rhipicephalus sanguineus: Sequential histopathology at the host-arthropode interface. Exp. Parasitol. 1974, 36, 77-105. [CrossRef]

41. Bechara, G.H.; Szabó, M.P.J.; Mukai, L.S.; Rosa, P.C.S. Immunisation of dogs, hamsters and guinea pigs against Rhipicephalus sanguineus using crude unfed adult tick extracts. Vet. Parasitol. 1994, 52, 79-90. [CrossRef]

42. Szabó, M.P.J.; Bechara, G.H. An insight into the histopathology caused by the tick Rhipicephalus sanguineus (Acarina: Ixodidae) in the skin of previously infested, vaccinated or tick-bite naive dogs, guinea pigs and hamsters. Braz. J. Vet. Res. Anim. Sci. 1995, 32, 37-42. [CrossRef] 
43. Szabó, M.P.J.; Mukai, L.S.; Rosa, P.C.S.; Bechara, G.H. Differences in the acquired resistance of dogs, hamsters, and guinea pigs to repeated infestations with adult ticks Rhipicephalus sanguineus (Acari: Ixodidae). Braz. J. Vet. Res. Anim. Sci. 1995, 32, 43-50. [CrossRef]

44. Szabó, M.P.J.; Bechara, G.H. Sequential histopathology at the Rhipicephalus sanguineus tick feeding site on dogs and guinea pigs. Exp. Appl. Acarol. 1999, 23, 915-928. [CrossRef]

45. Pappalardo, B.L.; Brown, T.; Gookin, J.L.; Morrill, C.L.; Breitschwerdt, E.B. Granulomatous disease associated with Bartonella infections in two dogs. J. Vet. Med. 2000, 14, 37-42.

46. Kumsa, B.E.; Mekonnen, S. Ixodid ticks, fleas and lice infesting dogs and cats in Hawassa, southern Ethiopia. Onderstepoort J. Vet. Res. 2011, 78, E326. [CrossRef]

47. Christensson, D.; Zakrisson, G. Ticks, Ixodes ricinus in the sub-cutaneous tissues of a dog and foxes. Svensk Vet. 2010, 62, 25-27. (In Swedish)

48. Atwell, R.B.; Campbell, F.E.; Evans, E.A. Prospective survey of tick paralysis in dogs. Aust. Vet. J. 2001, 79, 412-418. [CrossRef]

49. Adamantos, S.; Boag, A.; Church, D. Australian tick paralysis in a dog imported into the UK. Aust. Vet. J. 2005, 83, 352-353. [CrossRef] [PubMed]

50. Otranto, D.; Dantas-Torres, F.; Tarallo, V.D.; do Nascimento Ramos, R.A.; Stanneck, D.; Baneth, G.; de Caprariis, D. Apparent tick paralysis by Rhipicephalus sanguineus (Acari: Ixodidae) in dogs. Vet. Parasitol. 2012, 188, 325-329. [CrossRef] [PubMed]

51. Eppleston, K.R.; Kelman, M.; Ward, M.P. Distribution, seasonality and risk factors for tick paralysis in Australian dogs and cats. Vet. Parasitol. 2013, 196, 460-468. [CrossRef] [PubMed]

52. Leister, E.; Morton, J.; Atwell, R.; Webster, R. Clinical presentations, treatments and risk factors for mortality in cats with tick paralysis caused by Ixodes holocyclus: 2077 cases (2008-2016). J. Feline Med. Surg. 2018, 20, 465-478. [CrossRef]

53. Padula, A.M.; Leister, E.M.; Webster, R.A. Tick paralysis in dogs and cats in Australia: Treatment and prevention deliverables from 100 years of research. Vet. J. 2020, 98, 53-59. [CrossRef]

54. Hodžić, A.; Mateos-Hernández, L.; Leschnik, M.; Alberdi, P.; Rego, R.O.M.; Contreras, M.; Villar, M.; de la Fuente, J.; Cabezas-Cruz, A.; Duscher, G.G. Tick bites induce anti- $\alpha$-gal antibodies in dogs. Vaccines 2019, 7, 114. [CrossRef]

55. Becklund, W.W. Ticks of veterinary significance found on imports in the United States. J. Parasitol. 1968, 54, 622-628. [CrossRef]

56. Keirans, J.E.; Durden, L.A. Invasion: Exotic ticks (Acari: Argasidae, Ixodidae) imported into the United States. A review and new records. J. Med. Entomol. 2001, 38, 850-861. [CrossRef]

57. Liebisch, G.; Liebisch, A.; Paufler, S. Importation of a New World tick, Dermacentor albipictus (Acari: Ixodidae), with a horse from the USA into Germany. In Trends in Acarology, Proceedings of the 12th International Congress, Heraklion, Greece, 21-25 September 2016; Sabelis, M., Bruin, J., Eds.; Springer: Dordrecht, The Netherlands, 2010.

58. Navajas, M.; Migeon, A.; Estrada-Peña, A.; Mailleux, A.C.; Servigne, P.; Petanović, R.; Roques, A. Mites and ticks (Acari). Chapter 7.4. Arthropod invasions in Europe. BioRisk 2010, 4, 149-192. [CrossRef]

59. Schvartz, G.; Epp, T.; Burgess, H.J.; Chilton, N.B.; Armstrong, J.S.; Lohmann, K.L. Passive surveillance for ticks on horses in Saskatchewan. Can. Vet. J. 2015, 56, 486-489.

60. Chitimia-Dobler, L.; Schaper, S.; Rieß, R.; Bitterwolf, K.; Frangoulidis, D.; Bestehorn, M.; Springer, A.; Oehme, R.; Drehmann, M.; Lindau, A.; et al. Imported Hyalomma ticks in Germany in 2018. Parasites Vectors 2019, 12, 134. [CrossRef] [PubMed]

61. Simmons, L.A.; Burridge, M.J. Introduction of the exotic ticks Amblyomma humerale Koch and Amblyomma geoemydae (Cantor) (Acari: Ixodidae) into the United States on imported reptiles. Int. J. Acarol. 2000, 26, 239-242. [CrossRef]

62. Simmons, L.A.; Burridge, M.J. Introduction of the exotic tick Amblyomma chabaudi rageau (Acari: Ixodidae) into Florida on imported tortoises. Fla. Entomol. 2002, 85, 288-289. [CrossRef]

63. Burridge, M.J.; Simmons, L.A. Exotic ticks introduced into the United States on imported reptiles from 1962 to 2001 and their potential roles in international dissemination of diseases. Vet. Parasitol. 2003, 113, 289-320. [CrossRef]

64. Nowak-Chmura, M. Teratological changes in tick morphology in ticks feeding on exotic reptiles. J. Nat. Hist. 2012, 46, 911-921. [CrossRef]

65. Nowak-Chmura, M. A biological/medical review of alien tick species (Acari: Ixodida) accidentally transferred to Poland. Ann. Parasitol. 2014, 60, 49-59. [PubMed]

66. Paştiu, A.I.; Matei, I.A.; Mihalca, A.D.; D’Amico, G.; Dumitrache, M.O.; Kalmár, Z.; Sándor, A.; Lefkaditis, M.; Gherman, C.M.; Cozma, V. Zoonotic pathogens associated with Hyalomma aegyptium in endangered tortoise: Evidence for host-switching behavior in ticks? Parasites Vectors 2012, 5, 301-306. [CrossRef]

67. Mihalca, A.D. Ticks imported to Europe with exotic reptiles. Vet. Parasitol. 2015, 213, 67-71. [CrossRef]

68. Zygner, W.; Górski, P.; Wędrychowicz, H. Detection of the DNA of Borrelia afzelii, Anaplasma phagocytophilum and Babesia canis in blood samples from dogs in Warsaw. Vet. Rec. 2009, 164, 465-467. [CrossRef]

69. Schreiber, C.; Krücken, J.; Beck, S.; Maaz, D.; Pachnicke, S.; Krieger, K.; Gross, M.; Kohn, B.; von Samson-Himmelstjerna, G. Pathogens in ticks collected from dogs in Berlin/Brandenburg, Germany. Parasites Vectors 2014, 7, 535. [CrossRef]

70. Morganti, G.; Gavaudan, S.; Canonico, C.; Ravagnan, S.; Olivieri, E.; Diaferia, M.; Marenzoni, M.L.; Antognoni, M.T.; Capelli, G.; Silaghi, C.; et al. Molecular survey on Rickettsia spp., Anaplasma phagocytophilum, Borrelia burgdorferi sensu lato, and Babesia spp. in Ixodes ricinus ticks infesting dogs in Central Italy. Vector Borne Zoonotic Dis. 2017, 17, 743-748. [CrossRef] [PubMed]

71. Namina, A.; Capligina, V.; Seleznova, M.; Krumins, R.; Aleinikova, D.; Kivrane, A.; Akopjana, S.; Lazovska, M.; Berzina, I.; Ranka, R. Tick-Borne pathogens in ticks collected from dogs, Latvia, 2011-2016. BMC Vet. Res. 2019, 15, 398. [CrossRef] [PubMed] 
72. Mannelli, A.; Mandola, M.L.; Pedri, P.; Tripoli, M.; Nebbia, P. Associations between dogs that were serologically positive for Rickettsia conorii relative to the residences of two human cases of Mediterranean spotted fever in Piemonte (Italy). Prev. Vet. Med. 2006, 60, 13-26. [CrossRef]

73. Nicholson, W.L.; Allen, K.E.; McQuiston, J.H.; Breitschwerdt, E.B.; Little, S.E. The increasing recognition of rickettsial pathogens in dogs and people. Trends Parasitol. 2010, 26, 205-212. [CrossRef]

74. Król, N.; Obiegala, A.; Pfeffer, M.; Lonc, E.; Kiewra, D. Detection of selected pathogens in ticks collected from cats and dogs in the Wrocław Agglomeration, South-West Poland. Parasites Vectors 2016, 9, 351. [CrossRef]

75. Leschnik, M.W.; Kirtz, G.C.; Thalhammer, J.G. Tick-Borne encephalitis (TBE) in dogs. Int. J. Med. Microbiol. 2002, 291 (Suppl. 33), 66-69. [CrossRef]

76. Lindhe, K.E.; Meldgaard, D.S.; Jensen, P.M.; Houser, G.A.; Berendt, M. Prevalence of tick-borne encephalitis virus antibodies in dogs from Denmark. Acta Vet. Scand. 2009, 51, 56. [CrossRef]

77. Nelder, M.P.; Russell, C.B.; Sheehan, N.J.; Sander, B.; Moore, S.; Li, Y.; Johnson, S.; Patel, S.N.; Sider, D. Human pathogens associated with the blacklegged tick Ixodes scapularis: A systematic review. Parasites Vectors 2016, 9, 265. [CrossRef]

78. Tabar, M.D.; Roura, X.; Francino, O.; Altet, L.; Ruiz de Gopegui, R. Detection of Leishmania infantum by real-time PCR in a canine blood bank. J. Small Anim. Pract. 2008, 49, 325-328. [CrossRef]

79. Otranto, D.; Dantas-Torres, F. Canine and feline vector-borne diseases in Italy: Current situation and perspectives. Parasites Vectors 2010, 3, 2. [CrossRef]

80. Adem, P.V. Emerging and re-emerging rickettsial infections. Semin. Diagn. Pathol. 2019, 36, 146-151. [CrossRef] [PubMed]

81. Giudice, E.; Domina, F.; Britti, D.; Di Pietro, S.; Pugliese, A. Clinical findings associated with Borrelia burgdorferi infection in the dog. Vet. Res. Commun. 2003, 27 (Suppl. 1), 767-770. [CrossRef] [PubMed]

82. Giudice, E.; Giannetto, C.; Torina, A.; Gianesella, M. Anaplasma phagocytophilum intragranulocytic morulae in aborting sheep: A herd case in Sicily. Transbound. Emerg. Dis. 2011, 58, 263-267. [CrossRef]

83. Maia, C.; Campino, L. Methods for diagnosis of canine leishmaniasis and immune response to infection. Vet. Parasitol. 2008, 158, 274-287. [CrossRef]

84. Giulieri, S.; Jaton, K.; Cometta, A.; Trellu, L.T.; Greub, G. Development of a duplex real-time PCR for the detection of Rickettsia spp. and typhus group rickettsia in clinical samples. FEMS Immunol. Med. Microbiol. 2012, 64, 92-97. [CrossRef]

85. Adaszek, Ł.; Banach, T.; Bartnicki, M.; Winiarczyk, D.; Łyp, P.; Winiarczyk, S. Application the mass spectrometry MALDI-TOF technique for detection of Babesia canis canis infection in dogs. Parasitol. Res. 2014, 113, 4293-4295. [CrossRef]

86. Blanda, V.; D’Agostino, R.; Giudice, E.; Randazzo, K.; La Russa, F.; Villari, S.; Vullo, S.; Torina, A. New real-time PCRs to differentiate Rickettsia spp. and Rickettsia conorii. Molecules 2020, 25, 4431. [CrossRef]

87. Di Pietro, S.; Crinò, C.; Falcone, A.; Crupi, R.; Francaviglia, F.; Vitale, F.; Giudice, E. Parasitemia and its daily variation in canine leishmaniasis. Parasitol. Res. 2020, 119, 3541-3548. [CrossRef]

88. Dongus, H.; Zahler, M.; Gothe, R. Die braune Hundezecke, Rhipicephalus sanguineus (Ixodidae), in Deutschland: Eine epidemiologische Studie und Bekämpfungsmassnahmen [The brown dog tick, Rhipicephalus sanguineus (Ixodidae), in Germany: An epidemiologic study and control measures]. Berl. Münch. Tierärztl. Wochenschr. 1996, 109, 245-248. (In German)

89. Glaser, B.; Gothe, R. Imported arthropod-borne parasites and parasitic arthropods in dogs: Spectrum of species and epidemiological analysis of the cases diagnosed in 1995 and 1996. Tierärztl. Prax. 1998, 26, 40-46.

90. Glaser, B.; Gothe, R. Tourism and import of dogs: An inquiry in Germany on the extent as well as on the spectrum and preference of countries concerning stay abroad and origin, respectively. Tierärztl. Prax. 1998, 26, 197-202.

91. Hirsch, M.; Pantchev, N. Occurrence of the travel diseases leishmaniosis, ehrlichiosis, babesiosis and dirofilariosis in dogs living in Germany. Kleintierpraxis 2008, 53, 154-165. (In German)

92. Menn, B.; Lorentz, S.; Naucke, T.J. Imported and travelling dogs as carriers of canine vector-borne pat.ogens in Germany. Parasites Vectors 2010, 3, 34. [CrossRef] [PubMed]

93. Naucke, T.; Lorentz, S.; Menn, B.; Mencke, N. Prevalence of canine vector-borne pathogens in imported and travelling dogs in Germany and studies on the prevalence of CVBD. Tierärztl. Umsch. 2011, 66, 311-317.

94. Hamel, D.; Silaghi, C.; Pfister, K. Arthropod-Borne infections in travelled dogs in Europe. Parasite 2013, 20, 9. [CrossRef]

95. Schafer, I.; Weingart, C.; Kohn, B. Infection with Anaplasma phagocytophilum in a cat in Germany. Kleintierpraxis 2019, 64, 205-215. (In German)

96. Best, J.M.; Butt, K.M.; Rohrbach, J.A. Occurrence of Rhipicephalus sanguineus in London. Vet. Rec. 1969, 85, 633. [CrossRef]

97. Fox, M.T.; Sykes, T.J. Establishment of the tropical dog tick, Rh. sanguineus, in a house in London. Vet. Rec. 1985, 116, 661-662. [CrossRef]

98. Garben, A.F.; Bosman, B.T.; van Bronswijk, J.E. [The brown dog tick Rhipicephalus sanguineus Latreille 1806 in the Netherlands, an analysis of imported cases, including their veterinary and medical significance]. Tijdschr. Diergeneeskd. 1980, 105, 192-203. (In Dutch)

99. Jongejan, F.; de Jong, S.; Voskuilen, T.; van den Heuvel, L.; Bouman, R.; Heesen, H.; Carlijn Ijzermans, C.; Berger, L. “Tekenscanner": A novel smartphone application for companion animal owners and veterinarians to engage in tick and tick-borne pathogen surveillance in the Netherlands. Parasites Vectors 2019, 12, 116. [CrossRef]

100. Jaenson, T.G.; Jaenson, D.G.; Eisen, L.; Petersson, E.; Lindgren, E. Changes in the geographical distribution and abundance of the tick Ixodes ricinus during the past 30 years in Sweden. Parasites Vectors 2012, 5, 8. [CrossRef] [PubMed] 
101. Eichenberger, R.M.; Peter, D.; Alexander, M. Ticks on dogs and cats: A pet owner-based survey in a rural town in northeastern Switzerland. Ticks Tick Borne Dis. 2015, 6, 267-271. [CrossRef] [PubMed]

102. Földvári, G.; Márialigeti, M.; Solymosi, N.; Lukács, Z.; Majoros, G.; Kósa, J.P.; Farkas, R. hard ticks infesting dogs in Hungary and their infection with Babesia and Borrelia species. Parasitol. Res. 2007, 101, 25-34. [CrossRef]

103. Tsatsaris, A.; Chochlakis, D.; Papadopoulos, B.; Petsa, A.; Georgalis, L.; Angelakis, E.; Ioannou, I.; Tselentis, Y.; Psaroulaki, A. Species composition, distribution, ecological preference and host association of ticks in Cyprus. Exp. Appl. Acarol. 2016, 70, 523-542. [CrossRef]

104. Papazahariadou, M.G.; Saridomichelakis, M.N.; Koutinas, A.F.; Papadopoulos, E.G.; Leontides, L. Tick infestation of dogs in Thessaloniki, northern Greece. Med. Vet. Entomol. 2003, 17, 110-113. [CrossRef]

105. Zanet, S.; Battisti, E.; Pepe, P.; Ciuca, L.; Colombo, L.; Trisciuoglio, A.; Ferroglio, E.; Cringoli, G.; Rinaldi, L.; Maurelli, M.P. Tickborne pathogens in Ixodidae ticks collected from privately-owned dogs in Italy: A country-wide molecular survey. BMC Vet. Res. 2020, 16, 46. [CrossRef]

106. Estrada-Peña, A.; Roura, X.; Sainz, A.; Miró, G.; Solano-Gallego, L. Species of ticks and carried pathogens in owned dogs in Spain: Results of a one-year national survey. Ticks Tick Borne Dis. 2017, 8, 443-452. [CrossRef]

107. Dantas-Torres, F.; Maia, C.; Latrofa, M.S.; Annoscia, G.; Cardoso, L.; Otranto, D. Genetic characterization of Rhipicephalus sanguineus (sensu lato) ticks from dogs in Portugal. Parasites Vectors 2017, 10, 133. [CrossRef]

108. Claerebout, E.; Losson, B.; Cochez, C.; Casaert, S.; Dalemans, A.C.; De Cat, A.; Madder, M.; Saegerman, C.; Heyman, P.; Lempereur, L. Ticks and associated pathogens collected from dogs and cats in Belgium. Parasites Vectors 2013, 6, 183. [CrossRef]

109. Jameson, L.J.; Phipps, L.P.; Medlock, J.M. Surveillance for exotic ticks on companion animals in the UK. Vet. Rec. 2010, 166, 202-203. [CrossRef]

110. Tulloch, J.S.P.; McGinley, L.; Sánchez-Vizcaíno, F.; Medlock, J.M.; Radford, A.D. The passive surveillance of ticks using companion animal electronic health records. Epidemiol. Infect. 2017, 145, 2020-2029. [CrossRef] [PubMed]

111. Corrain, R.; Drigo, M.; Fenati, M.; Menandro, M.L.; Mondin, A.; Pasotto, D.; Martini, M. Study on ticks and tick-borne zoonoses in public parks in Italy. Zoonoses Public Health 2012, 59, 468-476. [CrossRef] [PubMed]

112. Di Luca, M.; Toma, L.; Bianchi, R.; Quarchioni, E.; Marini, L.; Mancini, F.; Ciervo, A.; Khoury, C. Seasonal dynamics of tick species in an urban park of Rome. Ticks Tick Borne Dis. 2013, 4, 513-517. [CrossRef] [PubMed]

113. Scarpulla, M.; Barlozzari, G.; Salvato, L.; De Liberato, C.; Lorenzetti, R.; Macrì, G. Rickettsia helvetica in human-parasitizing and free-living Ixodes ricinus from urban and wild green areas in the metropolitan city of Rome, Italy. Vector Borne Zoonotic Dis. 2018, 18, 404-407. [CrossRef] [PubMed]

114. Beyhan, Y.E.; Mungan, M.; Babur, C. The species of ticks bites on human and their seasonal distribution in Ankara, Turkey. Ank. Üniv. Vet. Fak. Derg. 2016, 63, 115-119.

115. Buczek, A.; Ciura, D.; Bartosik, K.; Zajac, Z.; Kulisz, J. Threat of attacks of Ixodes ricinus ticks (Ixodida: Ixodidae) and Lyme borreliosis within urban heat islands in south-western Poland. Parasites Vectors 2014, 7, 562. [CrossRef] [PubMed]

116. Kowalec, M.; Szewczyk, T.; Welc-Falęciak, R.; Siński, E.; Karbowiak, G.; Bajer, A. Rickettsiales occurrence and co-occurrence in Ixodes ricinus Ticks in natural and urban areas. Microb. Ecol. 2019, 77, 890-904. [CrossRef]

117. Reis, C.; Cote, M.; Paul, R.E.; Bonnet, S. 2011. Questing ticks in suburban forest are infected by at least six tick-borne pathogens. Vector Borne Zoonotic Dis. 2011, 11, 907-916. [CrossRef]

118. Rizzoli, A.; Silaghi, C.; Obiegala, A.; Rudolf, I.; Hubálek, Z.; Földvári, G.; Eplantard, O.; Evayssier-Taussat, M.; Bonnet, S.I.; Špitalská, E.; et al. Ixodes ricinus and its transmitted pathogens in urban and peri-urban areas in Europe. Front. Public Health 2014, 2, 251. [CrossRef]

119. Saleh, M.N.; Sundstrom, K.D.; Duncan, K.T.; Ientile, M.M.; Jordy, J.; Ghosh, P.; Litt, S.E. Show us your ticks: A survey of ticks infesting dogs and cats across the USA. Parasites Vectors 2019, 12, 595. [CrossRef]

120. Lorusso, V.; Dantas-Torres, F.; Lia, R.P.; Tarallo, V.D.; Mencke, N.; Capelli, G.; Otranto, D. Seasonal dynamics of the brown dog tick, Rhipicephalus sanguineus, on a confined dog population in Italy. Med. Vet. Entomol. 2010, 24, 309-315. [CrossRef] [PubMed]

121. Wright, I.; Cull, B.; Gillingham, E.L.; Hansford, K.M.; Medlock, J. Be tick aware: When and where to check cats and dogs for ticks. Vet. Rec. 2018, 182, 514. [CrossRef] [PubMed]

122. McColl, H.P.; Tenquist, J.D. Accidental importation of the brown dog tick, Rhipicephalus sanguineus. N. Z. Vet. J. 1980, $28,168-169$.

123. Hansford, K.M.; Pietzsch, M.E.; Cull, B.; Medlock, J.M. Importation of Rhipicephalus sanguineus into the UK via dogs. Vet. Rec. 2014, 175, 385-386. [CrossRef]

124. Bates, P.; Rankin, M.; Shickle, L. Importation of the brown dog or kennel tick (Rhipicephalus sanguineus) into the UK. Vet. Rec. 2002, 150, 224.

125. European Centre for Disease Prevention and Control and European Food Safety Authority. Mosquito Maps. Stockholm: ECDC. 2018. Available online: https://ecdc.europa.eu/en/disease-vectors/surveillance-and-disease-data (accessed on 12 December 2018).

126. Hunter, A.; Walker, A.; Sumption, K.; Eelesten, M.; Scott, G.; Sewell, M.; Morrow, A.; Hopper, D. Health risks from increased movement of companion animals in Europe. Vet. Rec. 1998, 142, 23.

127. Hoyle, D.V.; Walker, A.R.; Craig, R.S.; Woolhouse, M.E.J. Survey of parasite infections not endemic to the United Kingdom in quarantined animals. Vet. Rec. 2001, 149, 457-458. [CrossRef]

128. Trees, A.J.; Ridge, A. Threat of imported diseases to UK dogs. Vet. Rec. 2016, 178, 347. [CrossRef] 
129. Gillingham, E.L.; Cull, B.; Pietzsch, M.E.; Phipps, L.P.; Medlock, J.M.; Hansford, K. The unexpected holiday souvenir: The public health risk to UK travellers from ticks acquired overseas. Int. J. Environ. Res. Public Health 2020, 17, 7957. [CrossRef]

130. Gothe, R. On the occurrence of Rhipicephalus sanguineus (Latreille, 1806) in Germany. Z. Tropenmed. Parasitol. 1968, 19, 305-307. (In German)

131. Gothe, R. Rhipicephalus sanguineus (Ixodidae): Frequency of infestation and ehrlichial infections transmitted by this tick in dogs in Germany: An epidemiological study and consideration. Wiener Tierärtzl. Mon. 1999, 86, 49-56. (In German)

132. Gothe, R.; Hamel, H.D. Epizootics due to Rhipicephalus sanguineus (Latreille 1806) in Germany. Zent. Veterinärmed. B 1973, 20, 245-249. (In German) [CrossRef]

133. Centurier, C.; Gothe, R.; Hoffmann, G.; Liebisch, A.; Schein, E. [The brown dog tick Rhipicephalus sanguineus (Latreille, 1806) in Germany, a problem in small animal practice]. Berl. Münch. Tierärztl. Wochenschr. 1979, 92, 472-477. [PubMed]

134. Röhrig, E.; Hamel, D.; Pfister, K. Retrospective evaluation of laboratory data on canine vector-borne infections from the years 2004-2008. Berl. Münch. Tierärztl. Wochenschr. 2011, 124, 411-418.

135. Schäfer, I.; Volkmann, M.; Beelitz, P.; Merle, R.; Müller, E.; Kohn, B. Retrospective evaluation of vector-borne infections in dogs imported from the Mediterranean region and southeastern Europe (2007-2015). Parasites Vectors 2019, 12, 30. [CrossRef]

136. Szymański, S. Przypadek masowego rozwoju kleszcza Rhipicephalus sanguineus (Latreille, 1806) w warszawskim mieszkaniu [Case of a mass development of tick Rhipicephalus sanguineus (Latreille, 1806) in a Warsaw residence]. Wiad. Parazytol. 1979, 25, 453-459. (In Polish)

137. Černý, V. First case of introduction of the tick Rhipicephalus sanguineus to Czechoslovakia. Folia Parasitol. (Praha) $1985,32,162$.

138. Černý, V. Introduction of the tick Rhipicephalus sanguineus to Czechoslovakia: An additional case. Folia Parasitol. (Praha) 1989, $36,184$.

139. Van Bronswijk, J.E.M.H. A bibliography on ticks and tick-borne diseases in the countries of the Benelux (1567-1978). Vet. Q. 1980, 2, 220-233. [CrossRef]

140. Winding, O.; Haarløv, N. Accidental introduction into Denmark from Sudan of the kennel tick (Rhipicephalus sanguineus (Latr. 1806)). Nord. Veterinaermed. 1968, 20, 284-285.

141. Haarløv, N. Another case of introduction into Denmark from Africa of the kennel tick (Rhipicephalus sanguineus (Latr. 1806)). Nord. Veterinaermed. 1969, 21, 445-448.

142. Winding, O.; Willeberg, P.; Haarløv, N. Rhipicephalus sanguineus, an ectoparasite of dogs of current interest. Nord. Veterinaermed. 1970, 22, 48-58.

143. Willeberg, P. Forekomst af husflåt, Rhipicephalus sanguineus, i Danmark [Existence of the brown dog tick, Rhipicephalus sanguineus, in Denmark]. Ugeskr. Laeger 1970, 132, 1270-1271. (In Danish with Abstract in English) [PubMed]

144. Sibomana, G.; Geerts, S.; De Vries, T. Establishment of Rhipicephalus sanguineus (Latreille, 1806) inside houses in Belgium. Ann. Soc. Belg. Méd. Trop. 1986, 66, 79-81. [PubMed]

145. Péter, O.; Burgdorfer, W.; Aeschlimann, A.; Chatelanat, P. Rickettsia conorii isolated from Rhipicephalus sanguineus introduced into Switzerland on a pet dog. Z. Parasitenkd. 1984, 70, 265-270. [CrossRef]

146. Maurelli, M.P.; Pepe, P.; Colombo, L.; Armstrong, R.; Battisti, E.; Morgoglione, M.E.; Counturis, D.; Rinaldi, L.; Cringoli, G.; Ferroglio, E.; et al. A national survey of Ixodidae ticks on privately owned dogs in Italy. Parasites Vectors 2018, 11, 420. [CrossRef]

147. Kebbi, R.; Nait-Mouloud, M.; Hassissen, L.; Ayad, A. Seasonal activity of ticks infesting domestic dogs in Bejaia province, Northern Algeria. Onderstepoort J. Vet. Res. 2019, 86, e1-e6. [CrossRef]

148. Tinoco-Gracia, L.; Quiroz-Romero, H.; Quintero-Martínez, M.T.; Rentería-Evangelista, T.B.; González-Medina, Y.; BarrerasSerrano, A.; Hori-Oshima, S.; Moro, M.H.; Vinasco, J. Prevalence of Rhipicephalus sanguineus ticks on dogs in a region on the Mexico-USA border. Vet. Rec. 2009, 164, 59-61. [CrossRef]

149. Abah, O.O.I.; Audu, P.A. Prevalence of brown dog tick (Rhipicephalus sanguineus) infestation of dogs in Lokoja Metropolis, Kogi State, North-central, Nigeria. Niger. J. Parasitol. 2013, 34, 91-98.

150. Nithikathkul, C.; Polseela, R.; Iamsaard, J.; Wongsawad, C.; Jittapalapong, S. A study of ectoparasites of Canis lupus familiaris in Mueang district, Khon Kaen, Thailand. Southeast Asian J. Trop. Med. Public Health 2005, 36 (Suppl. 4), 149-151.

151. Ul-Hasan, M.; Abubakar, M.; Muhamad, G.; Khan, M.N.; Hussain, M. Prevalence of tick infestation (Rhipicephalus sanguineus and Hyalomma anatolicum anatolicum in dogs in Punjab, Pakistan. Vet. Ital. 2012, 48, 95-98. [PubMed]

152. Persichetti, M.F.; Solano-Gallego, L.; Serrano, L.; Altet, L.; Reale, S.; Masucci, M.; Pennisi, M.G. Detection of vector-borne pathogens in cats and their ectoparasites in southern Italy. Parasites Vectors 2016, 9, 247. [CrossRef] [PubMed]

153. Wright, I.; Wildgoose, W.H.; Wall, R.; McGarry, J. Rhipicephalus sanguineus in an imported dog. Vet. Rec. 2018, $182,25-26$.

154. Sparagano, O.A.; de Vos, A.P.; Paoletti, B.; Cammà, C.; de Santis, P.; Otranto, D.; Giangaspero, A. Molecular detection of Anaplasma platys in dogs using polymerase chain reaction and reverse line blot hybridization. J. Vet. Diagn. Investig. 2003, 15, 527-534. [CrossRef]

155. Alberti, A.; Addis, M.F.; Sparagano, O.; Zobba, R.; Chessa, B.; Cubeddu, T.; Parpaglia, M.L.; Ardu, M.; Pittau, M. Anaplasma phagocytophilum, Sardinia, Italy. Emerg. Infect. Dis. 2005, 11, 1322-1324. [CrossRef]

156. Uspensky, I. Brown dog tick or kennel tick, Rhipicephalus sanguineus (Latreille) (Acari: Ixodida: Ixodidae). In Encyclopedia of Entomology, 2nd ed.; Capinera, J.L., Ed.; Springer: Dordrecht, The Netherlands, 2008; Volume 1, pp. 577-580.

157. Cassini, R.; Zanutto, S.; di Regalbono, A.F.; Gabrielli, S.; Calderini, P.; Moretti, A.; Tampieri, M.P.; Pietrobelli, M. Canine piroplasmosis in Italy: Epidemiological aspects in vertebrate and invertebrate hosts. Vet. Parasitol. 2009, 165, 30-35. [CrossRef] 
158. Dantas-Torres, F.; Otranto, D. Further thoughts on the taxonomy and vector role of Rhipicephalus sanguineus group ticks. Vet. Parasitol. 2015, 208, 9-13. [CrossRef]

159. Santos, M.A.B.; de Souza, I.B.; de Macedo, L.O.; Ramos, C.A.D.N.; Rego, A.G.D.O.; Alves, L.C.; Ramos, R.A.N.; De Carvalho, G.A. Cercopithifilaria bainae in Rhipicephalus sanguineus sensu lato ticks from dogs in Brazil. Ticks Tick Borne Dis. 2017,8 , 623-625. [CrossRef]

160. Soares, R.L.; Silva, A.O.; Coelho, M.L.; Echeverria, J.T.; Souza, M.L.; Babo-Terra, V.J.; Pasquatti, T.N.; Ramos, R.A.N.; Ramos, C.A.N. Molecular detection of Cercopithifilaria bainae and other tick-borne pathogens in Rhipicephalus sanguineus s.l. isolated from dogs in Midwest Brazil. Braz. J. Vet. Parasitol. 2020, 29, e018019. [CrossRef]

161. Gehrke, F.S.; Gazeta, G.S.; Souza, E.R.; Ribeiro, A.; Marrelli, M.T.; Schumaker, T.T.S. Rickettsia rickettsii, Rickettsia felis and Rickettsia sp. TwKM03 infecting Rhipicephalus sanguineus and Ctenocephalides felis collected from dogs in a Brazilian spotted fever focus in the State of Rio De Janeiro/Brazil. Clin. Microbiol. Infect 2009, 15 (Suppl. 2), 267-268. [CrossRef]

162. Macaigne, F.; Pérez-Eid, C. Hyalomma scupense Schulze, 1919 (Acarina, Ixodoidea) tique autochtone du sud-ouest de la France. Ann. Parasitol. Hum. Comp. 1993, 68, 199-200. [CrossRef]

163. Vial, L.; Stachurski, F.; Leblond, A.; Hubera, K.; Vourc'h, G.; René-Martellet, M.; Desjardins, I.; Balançae, G.; Grosboise, V.; Pradier, S.; et al. Strong evidence for the presence of the tick Hyalomma marginatum Koch, 1844 in southern continental France. Ticks Tick Borne Dis. 2016, 7, 1162-1167. [CrossRef] [PubMed]

164. Hansford, K.M.; Pietzsch, M.E.; Cull, B.; Medlock, J.M. Surveillance: Brown dog tick infestation of a home in England. Vet. Rec. 2015, 176, 129-130. [CrossRef] [PubMed]

165. Renvoisé, A.; Delaunay, P.; Blanchouin, E.; Cannavo, I.; Cua, C.; Socolovschi, C.; Parola, P.; Raoult, D. Urban family cluster of spotted fever rickettsiosis linked to Rhipicephalus sanguineus infected with Rickettsia conorii subsp. caspia and Rickettsia massiliae. Ticks Tick Borne Dis. 2012, 3, 389-392. [CrossRef]

166. Latrofa, M.S.; Angelou, A.; Giannelli, A.; Annoscia, G.; Ravagnan, S.; Dantas-Torres, F.; Capelli, G.; Halos, L.; Beugnet, F.; Papadopoulos, E.; et al. Ticks and associated pathogens in dogs from Greece. Parasites Vectors 2017, 10, 301. [CrossRef]

167. Jameson, L.J.; Medlock, J.M. Tick surveillance in Great Britain. Vector Borne Zoonotic Dis. 2011, 11, 403-412. [CrossRef]

168. Wright, I. Exotic disease threats from pet travel, importation and changing parasite distributions in Europe. Vet. CPD $2017,4,3$.

169. Attipa, C.; Maguire, D.; Solano-Gallego, L.; Szladovits, B.; Barker, E.N.; Farr, A.; Baneth, G.; Tasker, S. Hepatozoon canis in three imported dogs: A new tickborne disease reaching the United Kingdom. Vet. Rec. 2018, 183, 716. [CrossRef]

170. Senneville, E.; Ajana, F.; Lecocq, P.; Chidiac, C.; Mouton, Y. Rickettsia conorii isolated from ticks introduced to northern France by a dog. Lancet 1991, 337, 676. [CrossRef]

171. Rovery, C.; Raoult, D. Mediterranean spotted fever. Infect. Dis. Clin. N. Am. 2008, 22, 515-530. [CrossRef]

172. Rovery, C.; Brouqui, P.; Raoult, D. Questions on Mediterranean spotted fever a century after its discovery. Emerg. Infect. Dis. 2008, 14, 1360-1367. [CrossRef] [PubMed]

173. Alieva, E.E.; Bondarenko, E.I.; Maliy, K.D.; Shvalov, A.N.; Verbenets, E.A.; Gafarova, M.T. The role of Rhipicephalus sanguineus ticks parasitizing dogs in the spread of tick-borne rickettsial pathogens in the city of Sevastopol. New Microbes New Infect. 2020, 36, 100704. [CrossRef] [PubMed]

174. Khrouf, F.; M'Ghirbi, Y.; Znazen, A.; Ben Jemaa, M.; Hammami, A.; Bouattour, A. Detection of Rickettsia in Rhipicephalus sanguineus ticks and Ctenocephalides felis fleas from southeastern Tunisia by reverse line blot assay. J. Clin. Microbiol. 2014, 52, 268-274. [CrossRef] [PubMed]

175. Bernasconi, M.V.; Casati, S.; Péter, O.; Piffaretti, J.-C. Rhipicephalus ticks infected with Rickettsia and Coxiella in Southern Switzerland (Canton Ticino). Infect. Genet. Evol. 2002, 2, 111-120. [CrossRef]

176. Edouard, S.; Parola, P.; Socolovschi, C.; Davoust, B.; La Scola, B.; Raoult, D. Clustered cases of Rickettsia sibirica mongolitimonae infection, France. Emerg. Infect. Dis. 2013, 19, 337-338. [CrossRef] [PubMed]

177. Oztoprak, N.; Celebi, G.; Aydemir, H.; Pişkin, N.; Bektaş, S.; Koca, R.; Kuloglu, F. Köpek kenesi ile temas sonrasinda gelişen akdeniz benekli ateşi [Mediterranean spotted fever due to contact with dog-tick]. Mikrobiyol. Bul. 2008, 42, 701-706. (In Turkish with English Abstract)

178. Solano-Gallego, L.; Morell, P.; Arboix, M.; Alberola, J.; Ferrer, L. Prevalence of Leishmania infantum infection in dogs living in an area of canine leishmaniasis endemicity using PCR on several tissues and serology. J. Clin. Microbiol. 2001, 39, 560-563. [CrossRef]

179. Lachaud, L.; Chabbert, E.; Dubessay, P.; Dereure, J.; Lamothe, J.; Dedet, J.P.; Bastien, P. Value of two PCR methods for the diagnosis of canine visceral leishmaniasis and the detection of asymptomatic carriers. Parasitology 2002, 125, 197-207. [CrossRef]

180. Mircean, V.; Dumitrache, M.O.; Györke, A.; Pantchev, N.; Jodies, R.; Mihalca, A.D.; Cozma, V. Seroprevalence and geographic distribution of Dirofilaria immitis and tick-borne infections (Anaplasma phagocytophilum, Borrelia burgdorferi sensu lato, and Ehrlichia canis) in dogs from Romania. Vector Borne Zoonotic Dis. 2012, 12, 595-604. [CrossRef]

181. Pennisi, M.G.; Caprì, A.; Solano-Gallego, L.; Lombardo, G.; Torina, A.; Masucci, M. Prevalence of antibodies against Rickettsia conorii, Babesia canis, Ehrlichia canis, and Anaplasma phagocytophilum antigens in dogs from the Stretto di Messina area (Italy). Ticks Tick Borne Dis. 2012, 3, 315-318. [CrossRef]

182. Morchón, R.; Carretón, E.; González-Miguel, J. Heartworm disease (Dirofilaria immitis) and their vectors in Europe-new distribution trends. Front. Physiol. 2012, 3, 196. [CrossRef] [PubMed]

183. Farkas, R.; Gyurkovszky, M.; Lukács, Z.; Aladics, B.; Solymosi, N. Seroprevalence of some vector-borne infections of dogs in Hungary. Vector Borne Zoonotic Dis. 2014, 14, 256-260. [CrossRef] [PubMed] 
184. Miró, G.; Montoya, A.; Roura, X.; Gálvez, R.; Sainz, A. Seropositivity rates for agents of canine vector-borne diseases in Spain: A multicentre study. Parasites Vectors 2013, 6, 117. [CrossRef] [PubMed]

185. Morganti, G.; Veronesi, F.; Stefanetti, V.; Di Muccio, T.; Fiorentino, E.; Diaferia, M.; Santoro, A.; Passamonti, F.; Gramiccia, M. Emerging feline vector-borne pathogens in Italy. Parasites Vectors 2019, 12, 193. [CrossRef] [PubMed]

186. Torina, A.; Caracappa, S. Dog tick-borne diseases in Sicily. Parassitologia 2006, 48, 145-147. [PubMed]

187. Díaz-Regañón, D.; Roura, X.; Suárez, M.L.; León, M.; Sainz, Á. Serological evaluation of selected vector-borne pathogens in owned dogs from northern Spain based on a multicenter study using a commercial test. Parasites Vectors 2020, 13, 301. [CrossRef]

188. Pantchev, N.; Vrhovec, M.G.; Pluta, S.; Straubinger, R.K. Seropositivity of Borrelia burgdorferi in a cohort of symptomatic cats from Europe based on a C6-peptide assay with discussion of implications in disease aetiology. Berl. Münch. Tierarztl. Wochenschr. 2016, $129,333-339$.

189. Izzard, L.; Cox, E.; Stenos, J.; Waterston, M.; Fenwick, S.; Graves, S. Serological prevalence study of exposure of cats and dogs in Launceston, Tasmania, Australia to spotted fever group rickettsiae. Aust. J. Vet. 2010, 88, 29-31. [CrossRef]

190. Montenegro, V.M.; Bonilla, M.C.; Kaminsky, D.; Romero-Zúñiga, J.J.; Siebert, S.; Krämer, F. Serological detection of antibodies to Anaplasma spp., Borrelia burgdorferi sensu lato and Ehrlichia canis and of Dirofilaria immitis antigen in dogs from Costa Rica. Vet. Parasitol. 2017, 236, 97-107. [CrossRef]

191. CDC. Centers for Disease Control, Prevention. Preventing Tick-Bites. 2017. Available online: https://www.cdc.gov/lyme/prev/ index.html (accessed on 1 June 2017).

192. European Scientific Counsel Companion Animal Parasites. ESCCAP Guideline 5: Control of Vector-Borne Diseases in Dogs and Cats, 3rd ed. 2019. Available online: https:/ / www.esccap.org (accessed on 30 January 2020).

193. Bissinger, B.W.; Roe, R.M. Tick repellents: Past, present, and future. Pestic. Biochem. Physiol. 2010, 96, 63-79. [CrossRef]

194. Phillips, C.B.; Liang, M.H.; Sangha, O.; Wright, E.A.; Fossel, A.H.; Lew, R.A.; Fossel, K.K.; Shadick, N.A. Lyme disease and preventive behaviors in residents of Nantucket Island, Massachusetts. Am. J. Prev. Med. 2001, 20, 219-224. [CrossRef]

195. Bartosik, K.; Kubrak, T.; Olszewski, T.; Jung, M.; Buczek, A. Prevention of tick bites and protection against tick-borne diseases in south-eastern Poland. Ann. Agric. Environ. Med. 2008, 15, 181-185. [PubMed]

196. Butler, A.D.; Sedghi, T.; Petrini, J.R.; Ahmadi, R. Tick-Borne disease preventive practices and perceptions in an endemic area. Ticks Tick Borne Dis. 2016, 7, 331-337. [CrossRef] [PubMed]

197. Eisen, L.; Dolan, M.C. Evidence for personal protective measures to reduce human contact with blacklegged ticks and for environmentally based control methods to suppress host-seeking blacklegged ticks and reduce infection with lyme disease spirochetes in tick vectors and rodent reservoirs. J. Med. Entomol. 2016, 53, 1063-1092.

198. Nejezchlebová, H.; Kiewra, D.; Žákovská, A.; Ovesná, P. Students' attitudes to tick risks. Ann. Agric. Environ. Med. 2016, 23, 437-441. [CrossRef]

199. Pańczuk, A.; Tokarska-Rodak, M.; Mikul'áková, W.; Kendrová, L.; Magurová, D. Exposure to ticks and undertaking Lyme borreliosis prevention activities among students from Poland and Slovakia. Ann. Agric. Environ. Med. 2019, 26, 217-221. [CrossRef]

200. Buczek, A.; Pilch, J.; Buczek, W. Tick preventive behaviors and practices adopted by medical students from Poland, Germany, and Thailand in relation to socio-demographic conditions and their knowledge of ticks and tick-borne diseases. Insects $2020,863$. [CrossRef]

201. Dumont, P.; Blair, J.; Fourie, J.J.; Chester, T.S.; Larsen, D.L. Evaluation of the efficacy of afoxolaner against two European dog tick species: Dermacentor reticulatus and Ixodes ricinus. Vet. Parasitol. 2014, 201, 216-219. [CrossRef]

202. Kunkle, B.; Daly, S.; Dumont, P.; Drag, M.; Larsen, D. Assessment of the efficacy of orally administered afoxolaner against Rhipicephalus sanguineus sensu lato. Vet. Parasitol. 2014, 201, 226-228. [CrossRef]

203. Six, R.H.; Young, D.R.; Holzmer, S.J.; Mahabir, S.P. Comparative speed of kill of sarolaner (Simparica) and afoxolaner (NexGard) against induced infestations of Rhipicephalus sanguineus s.l. on dogs. Parasites Vectors 2016, 9, 91. [CrossRef]

204. Cavalleri, D.; Murphy, M.; Gorbea, R.L.; Seewald, W.; Drake, J.; Nanchen, S. Laboratory evaluations of the immediate and sustained effectiveness of lotilaner $\left(\right.$ Credelio $^{\mathrm{TM}}$ ) against three common species of ticks affecting dogs in Europe. Parasites Vectors 2017, 10, 527. [CrossRef] [PubMed]

205. Becskei, C.; Fias, D.; Mahabir, S.P.; Farkas, R. Efficacy of a novel oral chewable tablet containing sarolaner, moxidectin and pyrantel (Simparica Trio ${ }^{\mathrm{TM}}$ ) against natural flea and tick infestations on dogs presented as veterinary patients in Europe. Parasites Vectors 2020, 13, 72. [CrossRef] [PubMed]

206. Coleman, N.; Coleman, S. Methods of tick removal: A systematic review of the literature. AMJ 2017, 10, 53-62. [CrossRef]

207. Buczek, A.M.; Buczek, W. Can freezing feeding ticks during removal from host skin be an effective method in prevention of tick-borne diseases? In Parasitic and Allergenic Arthropods; Buczek, A., Błaszak, C., Eds.; Koliber: Lublin, Poland, 2020; pp. 37-49.

208. Hoogstraal, H. African Ixodoidea. I. Ticks of the Sudan (with Special Reference to Equatoria Province and with Preliminary Reviews of the Genera Boophilus, Magaropus, and Hyalomma); U.S. Naval Medical Research Report NM 005 050.29.07; U.S. Navy: Philadelphia, PA, USA, 1956.

209. Hasle, G. Transport of ixodid ticks and tick-borne pathogens by migratory birds. Front. Cell. Infect. Microbiol. $2013,3,48$. [CrossRef]

210. Movila, A.; Alekseev, A.N.; Dubinina, H.V.; Toderas, I. Detection of tick-borne pathogens in ticks from migratory birds in the Baltic region of Russia. Med. Vet. Entomol. 2013, 27, 113-117. [CrossRef] 
211. Capek, M.; Literak, I.; Kocianova, E.; Sychra, O.; Najer, T.; Trnka, A.; Kverek, P. Ticks of the Hyalomma marginatum complex transported by migratory birds into Central Europe. Ticks Tick Borne Dis. 2014, 5, 489-493. [CrossRef]

212. Cohen, E.B.; Auckland, L.D.; Marra, P.P.; Hamer, S.A. Avian migrants facilitate invasions of neotropical ticks and tick-borne pathogens into the United States. Appl. Environ. Microbiol. 2015, 81, 8366-8378. [CrossRef]

213. Buczek, A.M.; Buczek, W.; Buczek, A.; Bartosik, K. The potential role of migratory birds in the rapid spread of ticks and tick-borne pathogens in the changing climatic and environmental conditions in Europe. Int. J. Environ. Res. Public Health 2020, $17,2117$. [CrossRef]

214. Beugnet, F.; Marié, J.-L. Emerging arthropod-borne diseases of companion animals in Europe. Vet. Parasitol. 2009, 163, 298-305. [CrossRef]

215. Mencke, N. Future challenges for parasitology: Vector control and 'One health' in Europe: The veterinary medicinal view on CVBDs such as tick borreliosis, rickettsiosis and canine leishmaniosis. Vet. Parasitol. 2013, 195, 256-271. [CrossRef]

216. Maia, C.; Ramos, C.; Coimbra, M.; Bastos, F.; Martins, Â.; Pinto, P.; Nunes, M.; Vieira, M.L.; Cardoso, L.; Campino, L. Bacterial and protozoal agents of feline vector-borne diseases in domestic and stray cats from southern Portugal. Parasites Vectors 2014, 7, 115. [CrossRef] [PubMed]

217. Willeberg, P.; Kjaersgaard, P. Babesiose hos en hund i Danmark [A case of canine babesiosis in Denmark]. Nord. Veterinaermed. 1973, 25, 308-312. (In Danish with Abstract in English). 